Sains Malaysiana 50(11)(2021): 3383-3394

http://doi.org/10.17576/jsm-2021-5011-22

\title{
Novel Deproteinized Natural Rubber Latex Adhesive Used in Extraoral Maxillofacial Prostheses
}

(Perekat Lateks Getah Asli Ternyahprotein Baharu yang Digunakan dalam Prostesis Maksilofasial Ekstraoral)

\author{
PAWEena KongKon, WiWAT Pichayakorn \& SASIWIMOL SANOHKAN*
}

\begin{abstract}
This study aimed to develop an adhesive for silicone maxillofacial prostheses and compared the properties with the Daro adhesive hydrobond (Factor II, Inc, Lakeside, AZ, USA). Two adhesives were developed from non-vulcanized natural rubber-based adhesives (Adhesive A) and deproteinized natural rubber latex (DNRL) products (Adhesive B) and stored at $4{ }^{\circ} \mathrm{C}$. The Control group was the commercial Daro adhesive hydrobond (Factor II, Inc, Lakeside, AZ, USA). The physical properties (appearance, viscosity, spreadability, color, and pH) of the adhesives were measured and every week for 12 weeks after storing at $4{ }^{\circ} \mathrm{C}$. The adhesives were characterized under scanning electron microscopy. Mechanical testing done were peel bond strength and biocompatibility testing was done using MTT assay. Physical, surface, and mechanical properties were compared with the commercial adhesive. Data analysis was done using SPSS version 24. Both adhesives were physically and chemically stable at temperature $4{ }^{\circ} \mathrm{C}$ and had suitable peel bond strength adhesives as the commercial adhesive. Hence, the adhesives can be used to adhere to the maxillofacial silicone prostheses.
\end{abstract}

Keywords: Deproteinized natural rubber; latex adhesive; maxillofacial silicone elastomer; rubber-based adhesives

\section{ABSTRAK}

Matlamat kajian ini ialah untuk membangunkan perekat prostesis maksilofasial silikon dan membandingkan sifatnya dengan perekat hidrobond Daro (Factor II, Inc., Lakeside, AZ, USA). Dua jenis perekat telah dibangunkan daripada perekat berjenis getah asli tak tervulkan (perekat A) dan lateks getah asli ternyahprotein (DNRL) (perekat B) dan disimpan pada suhu $4{ }^{\circ}$ C. Sifat fizikal (penampilan, kelikatan, kebolehsebaran, warna dan pH) perekat telah diukur. Sampel perekat telah dicirikan menggunakan mikroskop imbasan elektron. Ujian mekanik (kekuatan ikatan kupasan dan kebioserasian) telah dilakukan menggunakan MTT asai. Sifat fizikal, permukaan dan mekanik sampel telah dibandingkan dengan perekat komersial. Analisis data telah dilakukan menggunakan SPSS versi 24. Didapati kedua-dua sampel perekat stabil pada suhu $4{ }^{\circ} \mathrm{C}$ dan mempunyai kekuatan ikatan kupasan yang setara dengan perekat komersial. Oleh itu, perekat yang dibangunkan sesuai digunakan dalam rekatan prostesis maksilofasial.

Kata kunci: Elastomer silikon maksilofasial; getah semula jadi ternyahprotein; perekat jenis getah; perekat lateks

\section{INTRODUCTION}

Maxillofacial prosthetic devices are important in the rehabilitation of patients with facial defects. Silicone elastomer is a popular material for the fabrication of maxillofacial prostheses because of its suitable mechanical and physical properties (Amornvit et al. 2019; Charoenkijkajorn \& Sanohkan 2020). The maxillofacial prostheses can be retained from mechanical, anatomic, adhesive, and craniofacial implants (Amornvit et al. 2019; Jazayeri et al. 2018; Thongpulsawasdi et al. 2014). The adhesives play an important role in the adherence of the extraoral prostheses to the skin (Huber \& Studer 2002; Thongpulsawasdi et al. 2014). The adhesive bond strength should be adequate for the prosthesis to the skin as well as complete removable after de-bonding. Besides, the adhesive should be non-allergic and non-irritating to the skin and easily manipulated by the patient.

There has been little improvement in the adhesives used for the retention of the maxillofacial prostheses. The silicone-based adhesive introduced decades ago have 
inherent inadequacies organic solvent-based adhesives as ethyl acetate giving severe irritation reaction to skin (Dahl \& Polyzois 2000). Whereas, the water-based adhesive frequently lacks an adequate adhesion and present a visible margin between prostheses and the skin (Haug et al. 1995; Kiat-amnuay et al. 2008 ; Polyzois \& Dahl 1993). Also, these adhesives are expensive for the patients.

Natural rubber latex (NRL) can be extracted from Hevea brasiliensis (Sakdapipanich \& Rojruthai 2012). NRL exhibited various favorable properties such as easy film ability, good flexibility, impermeability to gases and liquids, and good oil resistance suitable to develop an adhesive (Suksaeree et al. 2014). Studies have reported that blending tackifier resins, vulcanizing agents, and NRL improved its wettability and bond strength to the substrate to achieve adhesion and tack value of adhesive (Sherriff et al. 1973). However, there have been several reports of latex allergies from NRL proteins and rubber additives. Also, ammonia, which is used preservative contained commercial NRL is not suitable for skin dosage forms (Sommer et al. 2002; Taylor \& Erkek 2004; Ventura et al. 2001). Thus, deproteinized processes are used to remove these protein allergens from NRL (Nanti et al. 2014; Perrella \& Gaspari 2002; Pichayakorn et al. 2014b). There were reports deproteinized natural rubber latex (DNRL) polymer blends as a material for medical and pharmaceutical skin applications, such as in transdermal drug delivery, peel-off mask, and cosmetic pore packs (Pichayakorn et al. 2014a, 2013a, 2013b, 2012c).

In this study, two adhesive formulations were developed from non-vulcanized natural rubber-based adhesives, vulcanized natural rubber-based adhesives, and pharmaceutical DNRL products for skin and test surface, mechanical and adhesive properties, and biocompatibility.

\section{Materials AND Methods}

\section{MATERIALS}

Materials and chemical agents used in this study are shown in Table 1. All chemicals were analytical grade. Commercial Daro adhesive hydrobond (Factor II, Inc, Lakeside, AZ, USA) was made as the control. Polyvinyl acetate (PVA) Mw 67,000 was used to form blended polymers with DNRL. Glycerine was added as plasticizers. Coumarone indene resin, zinc diethyldithiocarbamate (ZDEC), and sulfur were used as a tackifier and vulcanizing agents, respectively.

\section{ADHESIVES}

Fresh rubber latex without any preservative added was deproteinized by alcalase enzyme treatment and processed the centrifugation to obtain deproteinized natural rubber latex (DNRL). In brief, DNRL was prepared by proteolytic alcalase enzymes followed by centrifugation for 10,000 rpm 2 times (45 min and $30 \mathrm{~min}$ ) to remove the allergenic protein from fresh NRL as mentioned by Pichayakorn et al. (2012d). Two adhesives formulations (Test groups) were developed from non-vulcanized natural rubber-based adhesives (Adhesive A) and pharmaceutical DNRL products (Adhesive B) from $100 \mathrm{phr}$ 60\% w/v DNRL (Table 2).
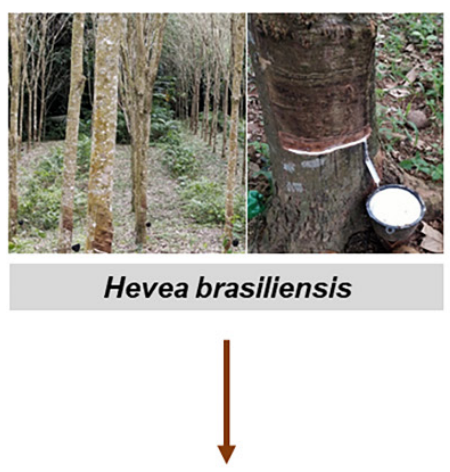<smiles>C=C(C)CCOP(=O)(O)OP(=O)([O-])O</smiles>

Isopentenyl Pyrophosphate

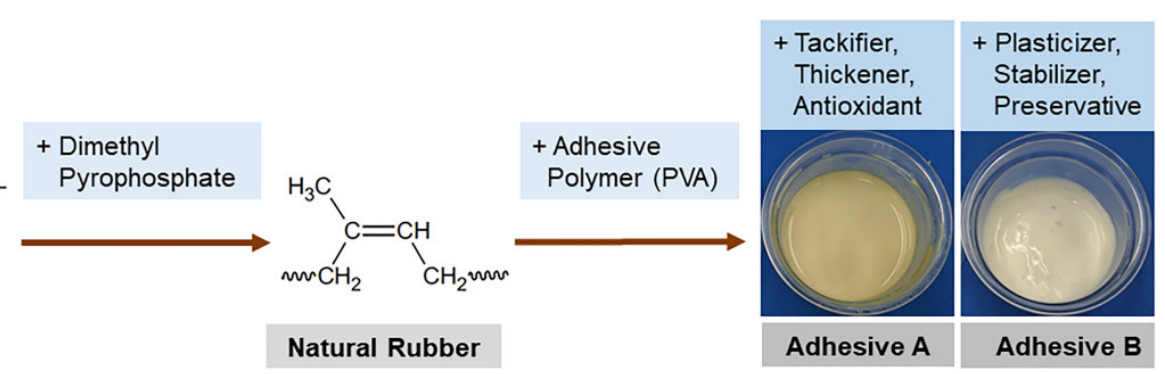

FIGURE 1. Preparation of the Adhesive A and Adhesive B 
In addition, Adhesive A contained 15 phr 20\% PVA, 40 phr $50 \%$ cumarone resin, 1 phr $2 \%$ methylcellulose, and 1 phr $50 \%$ Wingstay L. and Adhesive B contain 10 phr glycerine, 1 phr Tween 80 (stabilizer), and 0.25 phr Paraben (preservative) (Figure 1 and Table 1). After the preparation, Adhesive $\mathrm{A}$ and $\mathrm{B}$ were stored at $4{ }^{\circ} \mathrm{C}$ after mixing.

TABLE 1. Formulations for Adhesive A and Adhesive B

\begin{tabular}{|c|c|c|c|c|}
\hline \multirow{2}{*}{ Components } & \multirow{2}{*}{ Function } & \multirow{2}{*}{ Manufacturer } & \multicolumn{2}{|c|}{ Formulation (phr) } \\
\hline & & & Adhesive A & Adhesive B \\
\hline $60 \%$ DNRL & Main component & Processed & 100 & 100 \\
\hline $20 \%$ PVA & Adhesive polymer & Sigma-aldrich, USA & 15 & 15 \\
\hline $50 \%$ Coumarone resin & Tackifier resin & Vega ball, Thailand & 40 & - \\
\hline $2 \% \mathrm{CMC}$ & Thickener & LOBA Chemie, India & 1 & - \\
\hline 50\% Wingstay L. & Antioxidant & LOBA Chemie, India & 1 & - \\
\hline Glycerin & Plasticizer & Ajax Finechem, Australia & - & 10 \\
\hline Tween 80 & Stabilizer & LOBA Chemie, India & - & 1 \\
\hline Paraben & Preservative & SK Herb, Thailand & - & 0.25 \\
\hline
\end{tabular}

Silicone Strips Silicone strips of size $60 \times 10 \times 3 \mathrm{~mm}$ were prepared from silicone elastomers MDX4-4210 (Dow Corning Corp, Midland, MI, USA) in gypsum mold using manufacturer's recommendations. The elastomer strips were cured for $72 \mathrm{~h}$ at room temperature before testing.

Experimental Details. Physical Properties. Appearance and Color Appearance and colour of the adhesives after the set were examined with naked eye. A diameter of 0.1 gram of each adhesive (Adhesive A, Adhesive B, and Control) was placed between the two glass plates $(7.5 \mathrm{~cm} \times 7.5 \mathrm{~cm}$ size, weight 25 gram $)$ for one minute. The spreadability of each adhesive was measured. The experiment was repeated three times and compared among the groups. The $\mathrm{pH}$ of each adhesive was measured with a $\mathrm{pH}$ meter (Seven Easy S-20, Mettler Toledo, Switzerland) at room temperature. The glass electrode was calibrated with standard buffer solutions

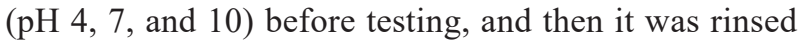
with distilled water between samples measurement before each use. These measurements were determined in triplicate and compared among the groups. The viscosity and flow behavior of each adhesive were measured with a rheometer (DHR2, TA Instruments Inc., New Castle, DE, USA) with the spindle SC4-31 at $25 \pm 2$ ${ }^{\circ} \mathrm{C}$ and various speeds of 50-250 rpm. These parameters were measured in triplicate and compared among the groups.

Stability The stability of each formulated adhesive investigated every weeks for their physical appearance, colour, phase separation, and homogeneity for 12 weeks. Mechanical properties (T-peel testing) The peel bond strengths of two adhesive formulations were investigated by the T-peel method which was modified from ASTM D1876-2375 using a cleaned poly(vinyl chloride) transparent sheet as substrate shown in Figure 2. The substrates and silicone strip were bonded only over approx. $30 \mathrm{~mm}$ of their length by the test adhesives and commercial adhesive as the positive control, DNRL, and PVA as the negative control $(\mathrm{n}=10)$. The adhesive strips were peeled after $3 \mathrm{~h}$ bonding with the cross-head speed at $100 \mathrm{~mm} / \mathrm{min}$ using the universal testing machine (Lloyd Instruments, LRX-Plus, AMETEK Lloyd Instrument Ltd., Hampshire, UK) at $23{ }^{\circ} \mathrm{C}$ and $50 \%$ relative humidity. The 
maximum forces at the failure beginning were recorded and the peel bond strength was calculated from this equation: where PS is the peel bond strength (N.m); F is the maximum force at the point of the failure beginning $(\mathrm{N})$; and $\mathrm{W}$ is the width of the specimen (mm).

$$
\mathrm{PS}=\mathrm{F} / \mathrm{W}
$$

(a)

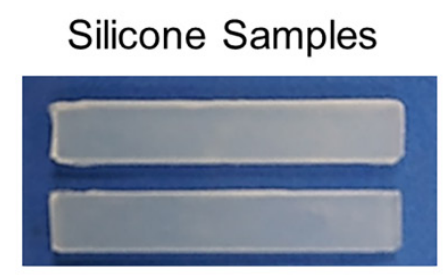

Bonding of plastic strip to silicone sample using an adhesive

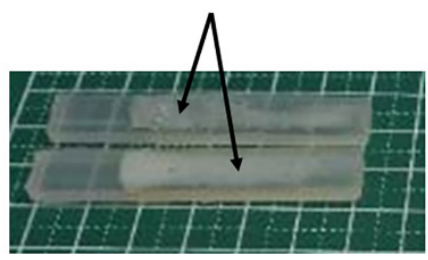

(b)

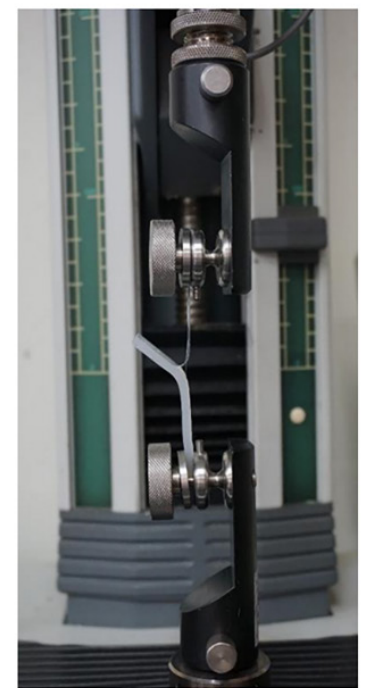

(c)

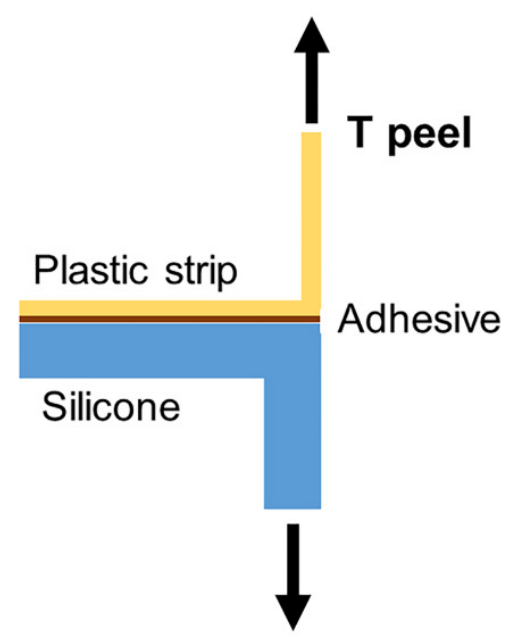

FIGURE 2. T-peel testing. Silicone sample preparation (a), instrument set up for the T-peel (b), and diagrammatic representation of T-peel testing (c)

Biocompatibility Testing Cell Viability Study Biocompatibility testing of the adhesives was done from the cell viability following the ethical approval. At first, the silicone discs were prepared from MDX4-4210 and mixed base/catalyst ratio 10:1. These silicones discshaped (14 mm diameter, $1.2 \mathrm{~mm}$ thickness) samples were fabricated and polymerized in gypsum mold. The elastomers were self-cured for $72 \mathrm{~h}$. The silicone disc was divided into five groups, as follows: blank; pure silicone disc (negative control); silicone disc with Daro adhesive (positive control); silicone disc with adhesives A; and silicone disc with Adhesive B (Figure 3). Before the cytotoxicity testing, the polymerized silicone elastomer specimens were sterilized in gaseous sterilization for $4 \mathrm{~h}$ at $55^{\circ} \mathrm{C}$ to prevent bacterial contamination.

The cells that were used for cytotoxicity testing are human immortalized non-tumorigenic keratinocyte cell line HaCaT (Ethnicity, Caucasian; Age, 62 years; gender, Male and tissue, skin; CLS Cell Lines Service, Eppelheim, Germany) following ISO 10993-5. The $\mathrm{HaCaT}$ cells were grown as monolayer cultures in $\mathrm{T}-25$ flasks, sub-cultured three times a week at $37{ }^{\circ} \mathrm{C}$, in an atmosphere of $5 \% \mathrm{CO}_{2}$ in the air and $100 \%$ relative humidity and maintained at third passage. The culture medium was supplemented by DMEM with $10 \%$ (v/v) fetal bovine serum (FBS), 1\% penicillin-streptomycin and $0.1 \%$ antibiotic/antimycotic solution antibiotic. The adherent cells were detached with a mixture of $0.25 \%$ trypsin-EDTA, incubated for $2-5 \mathrm{~min}$ at $37^{\circ} \mathrm{C}$. The $\mathrm{HaCaT}$ cell suspension with DMEM with $10 \%$ FBS was prepared at a concentration of $2.5 \times 10^{4}$ cells $/ \mathrm{mL}$ and incubated onto 96 -well cluster cell culture plates $(200 \mu \mathrm{L}$ per well). The selected DNRL adhesives and Daro adhesive were applied on a silicone disc. Allow to dry until the adhesive turns clear, then these discs were incubated in media for $24 \mathrm{~h}$ at $37^{\circ} \mathrm{C}$. The ratio of the surface area of the disc samples to the extraction volume is $3 \mathrm{~cm}^{2} / \mathrm{mL}$ in the present study, which is in line with ISO 109935:2009 (ISO, 2009). After the incubation periods, the extracts were filtered through $0.22 \mu \mathrm{m}$ cellulose acetate filters (Milipore; Sigma) and then were used to evaluate cytotoxicity. 


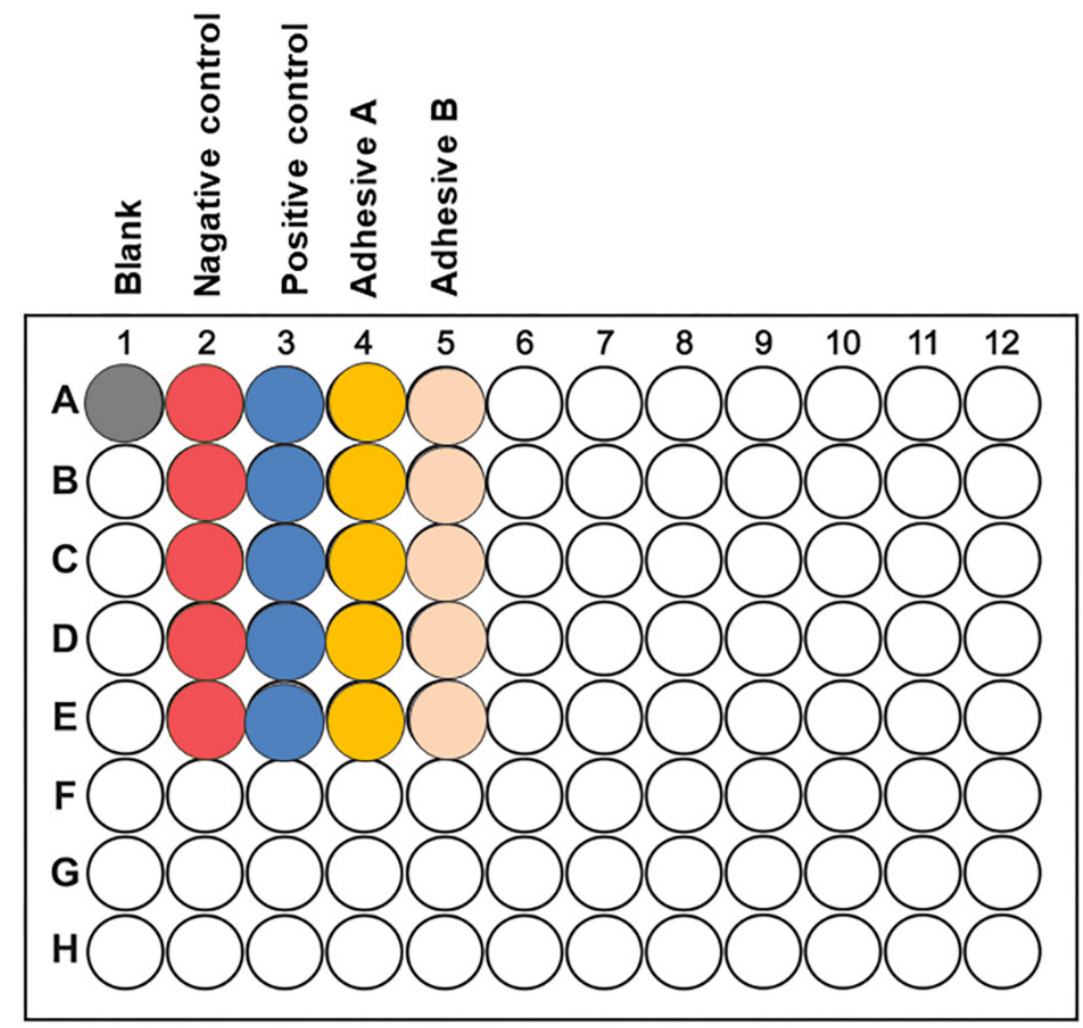

FIGURE 3. Biocompatibility testing of the adhesives was done from the cell viability

The multi-well plates were incubated at $37{ }^{\circ} \mathrm{C}$, $5 \% \mathrm{CO}_{2}$ in the air for $24 \mathrm{~h}$. The culture medium was removed from the wells and equal volumes $(200 \mu \mathrm{L})$ of the extracts were added into each well. In control wells, $200 \mu \mathrm{L}$ media were added. Then, 96-well cluster cell culture plates were incubated at $37{ }^{\circ} \mathrm{C}$ for $24 \mathrm{~h}$, $48 \mathrm{~h}$, and $72 \mathrm{~h}$ (Figure 8). Following removal of the test extracts media and replace it with $100 \mu \mathrm{L}$ of PBS for washing the cell. After removing the PBS, the MTT solution (tetrazolium salt 3-[4,5 dimethylthiazol-2-yl]2,5-diphenyltetrazolium bromide) $100 \mu \mathrm{L}$ of $5 \mathrm{mg} / \mathrm{mL}$ were added to each well. Culture plates were covered with aluminum foil to protect them from light and cells incubated in a dark environment at $37^{\circ} \mathrm{C}$ for $4 \mathrm{~h}$. After incubation, 96-wells were removed from MTT solution and replaced with DMSO $100 \mu \mathrm{L}$ to dissolve formazan product at $37^{\circ} \mathrm{C}$ for $30 \mathrm{~min}$. The formazan crystals were read absorbance at $570 \mathrm{~nm}$ using a spectrophotometer (Biotrak II Visible Plate reader, Amersham Biosciences Co., Piscataway, NJ, USA). The survival rates of the controls were set to represent $100 \%$ proliferation. The control well was consisting of untreated cell cultures. Five replicates of each extract and control were performed. The assay was carried out in the three independent experiments. The percentage of living cells (viability $\%)$ can be determined using the average optical density (OD) of the control wells and the wells containing the experimental groups.

$$
\text { Viability } \%=\frac{\text { Average OD of treated wells }}{\text { Average OD of control wells }} \times 100
$$

The lower percentage viability value indicates higher cytotoxic potential of the test item. If viability is reduced to $<70 \%$ of the control, that agent has a cytotoxic potential. DNRL adhesive with satisfied cytotoxicity was selected for further experiments.

Scanning electron microscopy (SEM) micrographs analysis The surface and cross-section morphologies of the adhesive were examined using SEM. The adhesives were dried at $37^{\circ} \mathrm{C}$ for $72 \mathrm{~h}$ and broken down using liquid nitrogen. Their specimens were sputtered with gold in a sputter coater (SPI-module). Their morphologies were immediately photographed with FEI Quanta 400 SEM at 
a magnification of 500x and 5,000x at an accelerating voltage of $1.5 \mathrm{kV}$.

Statistical analysis Descriptive statistics were calculated. Data analysis was done using SPSS version 24 (IBM, Corp.; Armonk, NY, USA). Test for the normality was done using the Kolmogorov Smirnov test and homogeneity of variance were carried out using the Shapiro-Wilk test for all the measured, respectively. The comparison of spreadability and T-peel testing was done using One-way ANOVA. The significance level was set at $\mathrm{P}$-value 0.05 . The cell viability was compared using Twoway ANOVA.

\section{RESULTS}

In this study, the adhesive properties of DNRL was improved by blending it with adhesive polymers, tackifiers, and/or vulcanizing agent, and plasticizers in order to develop the novel DNRL adhesive for adheringmaxillofacial silicone elastomer on human skin. The formulation contains different components, such as elastomers (natural rubber and synthesis rubber), tackifiers, plasticizers, vulcanizing agents, antioxidants, solvents, thickeners, and other additives, determined various properties.

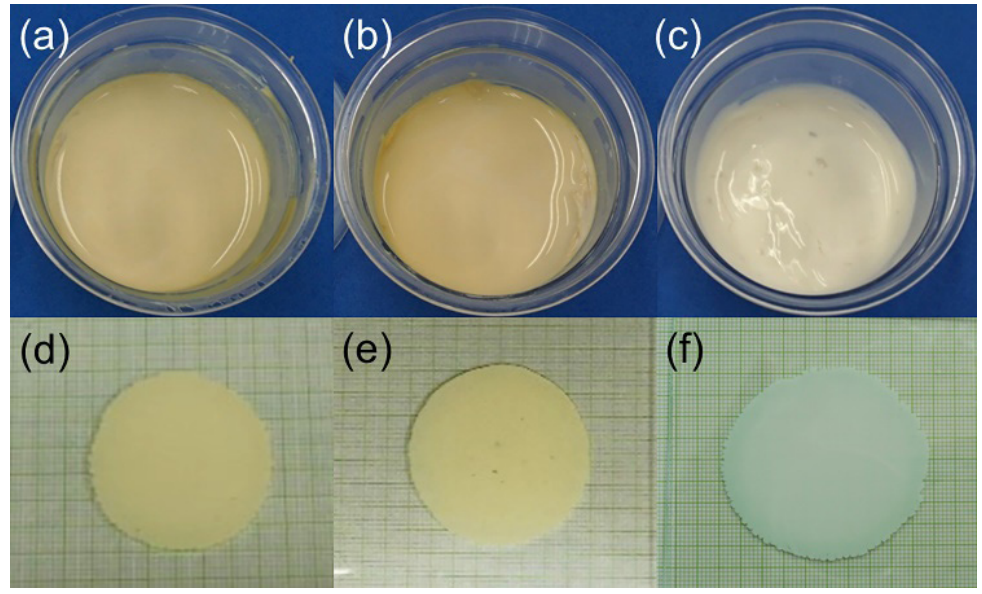

FIGURE 4. Physical appearance and spreadability of the Adhesive A, Adhesive B, and Control

Physical properties The physical appearance of Adhesive A, Adhesive B, and Control was similar. The colour of Adhesive A and Adhesive B was yellowish-brown whereas that of Control Adhesive was white (Figure 4). The viscosity of the adhesives was similar to that of the control adhesive. For the spreadability, there was no significant difference among the test groups (Figure 4, Table 2), but the test groups showed significantly lower spreadability compared to the control adhesive $(P>0.05)$. The $\mathrm{pH}$ of tested Adhesives was suitable (between 4-7) for use on human skin.

TABLE 2. The spreadability of each adhesive tested and the control group

\begin{tabular}{lcc}
\hline Sample & Spreadability $(\mathrm{mm})$ & $\mathrm{pH}$ \\
\hline Adhesive A & $39.00 \pm 1.32$ & $6.40 \pm 0.09$ \\
Adhesive B & $38.33 \pm 1.04$ & $7.09 \pm 0.05$ \\
Adhesive C & $38.33 \pm 0.76$ & $5.73 \pm 0.08$ \\
Hydrobond-Daro & $45.17 \pm 1.04^{*}$ & $7.69 \pm 0.07$ \\
\hline
\end{tabular}

*Significant difference at $\mathrm{P}<0.05$ 
The spreadability of these adhesives is the ability to evenly spread the skin and achieve bond strength (Landrock \& Ebnesajjad 2008). The spreading value were observed after one minute which showed that these adhesives had comparable spreadability with commercial products. The $\mathrm{pH}$ value of the adhesives was similar to the normal $\mathrm{pH}$ value of the skin. The novel adhesive had a lower viscosity when applied stress to enable an application. These parameters play an important role in their performance on the skin. The $\mathrm{pH}$, spreadability, and viscosity of novel adhesive indicated their safety and ease to be applied directly on the skin.

The viscosity curve of the adhesives showed nonNewtonian fluid behavior in which the viscosity value decreased when shear increased which was similar to the commercial adhesive as shown in Figure 5.

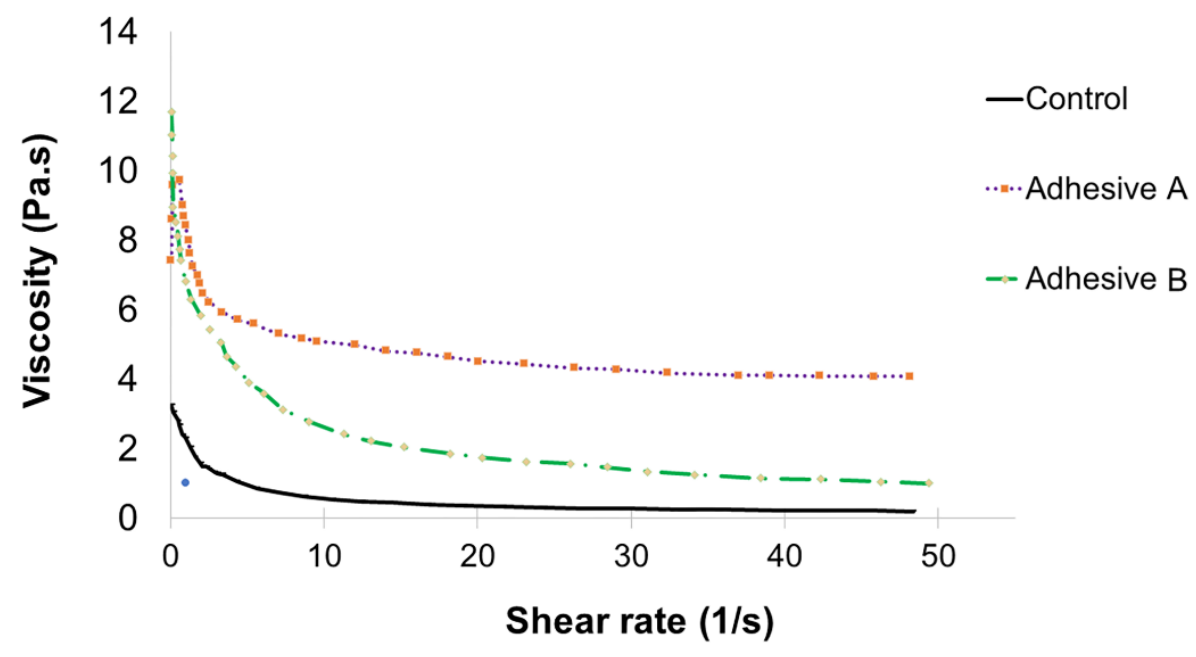

FIGURE 5. The viscosity curve of the Adhesive A, Adhesive B, and the Control showing the non-Newtonian fluid behavior

Mechanical properties (T-peel testing). The results of T-peel bond strength are shown in Figure 6. It showed that Adhesive A and Adhesive B showed similar peel bond strengths. There was no significant difference in the T-peel bond strength of Adhesive A and Adhesive B compared to the control $(P<0.05)$.

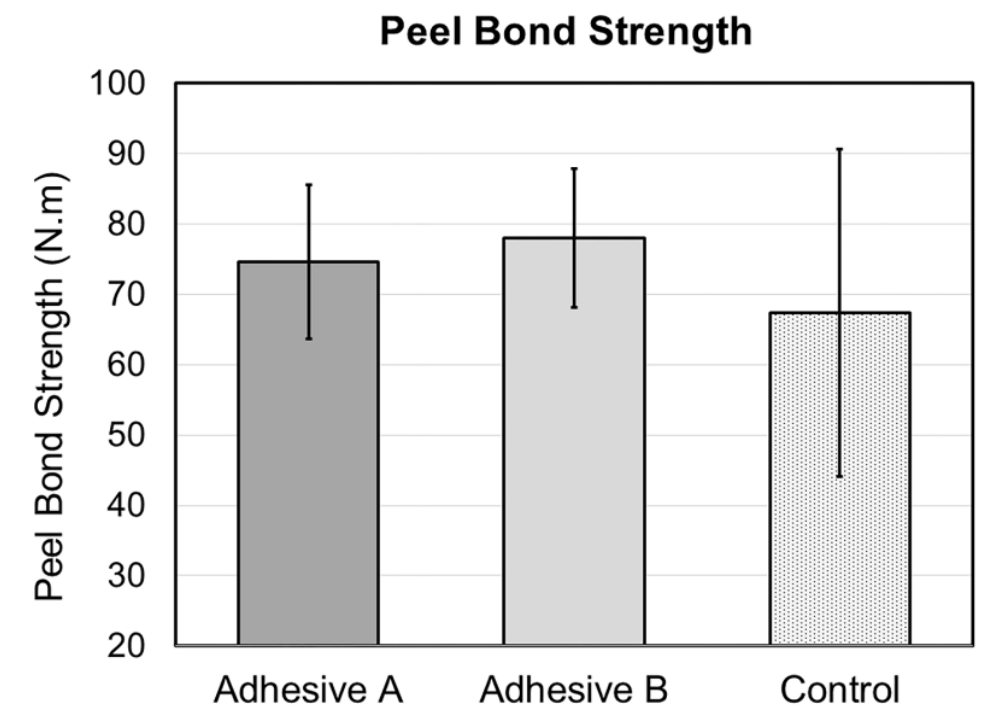

FIGURE 6. The results of T-peel bond strength in Adhesive A, Adhesive B, and the Control 
The study was done by T-peel testing to find the proper adhesive formulations and stability study. The peel tests are chosen for use in the study because these tests are more meaningful in predicting the ability of a material to bond in a clinical setting and stimulate the horizontal component of the peeling force that is generated while the patient is pulling the prosthesis out of the defect site. This dislodging action may cause stripping of the silicone at the border of prostheses (Khan \& Poh 2011b; Pizzi \& Mittal 2003). The material characteristics and stability of adhesive were studied in order to evaluate adhesive performance and indicate their safety on the skin.

The peel bond strengths were not significantly different from non-vulcanized and vulcanized natural rubber-based adhesives opposite to the previous study showed that the vulcanized natural rubber-based adhesive is higher adhesion to the substrate than non-vulcanized adhesive (Benedek \& Feldstein 2008). Moreover, the results of changing of adhesive appearance on this study found that the crosslink adhesives showed agglomerate of rubber molecule at 4 weeks after had been kept in $4{ }^{\circ} \mathrm{C}$ affect to the molecular weight of DNRL to over optimum molecular weight and decrease bond strength due to low wettability (Khan \& Poh 2011a).

Biocompatibility Testing The results of biocompatibility testing from MTT Assay at $24 \mathrm{~h}, 48 \mathrm{~h}$, and $72 \mathrm{~h}$ are shown in Figure 7. It showed that Adhesive A and Adhesive B had similar percentage viability. There was no significant difference in the percentage viability of Adhesive A and Adhesive B compared to the Control $(P<0.05)$.

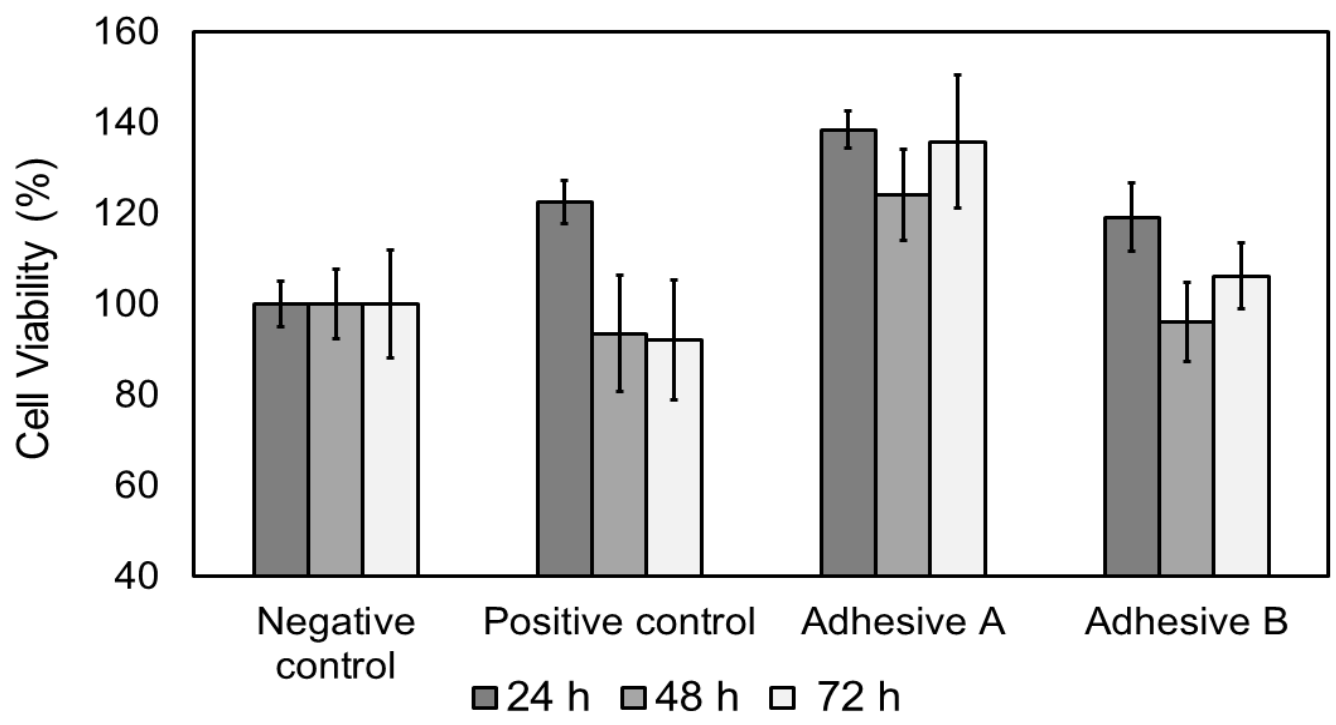

FIGURE 7 The results of biocompatibility testing using MTT Assay at $24 \mathrm{~h}, 48 \mathrm{~h}$, and $72 \mathrm{~h}$. Negative control: pure silicone disc and Positive control: silicone disc with Daro adhesive

Scanning electron microscopy (SEM) micrographs analysis The SEM images were used to study the highresolution microscopic morphology of control, adhesive A and B films (Figure 8). On surface view, the Control had a smooth outer surface compared with those of adhesive film (A and B). In contrast, the SEM of the adhesive $A$ showed a rough surface with agglomeration, whereas the adhesive $\mathrm{B}$, which contained plasticizer, had relatively several cracks on the surface and cross-section view due to the rapid evaporation in the preparation process. Moreover, adhesive A showed aggregation on the surface. On cross-section morphology view, Adhesive A and B showed a dense matrix without pore and Adhesive A shows rougher structure compared to Control and Adhesive B which may be due to the presence of Coumarone resin as a tackifier resin. 


\section{Surface}

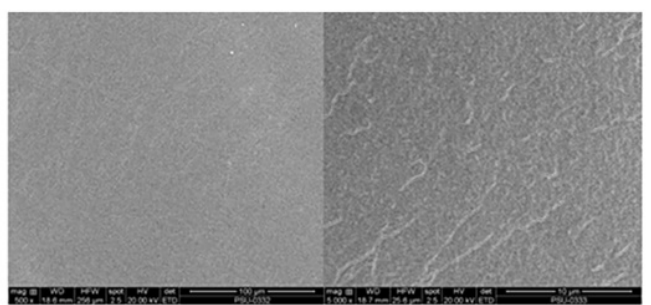

Control

Adhesive

A

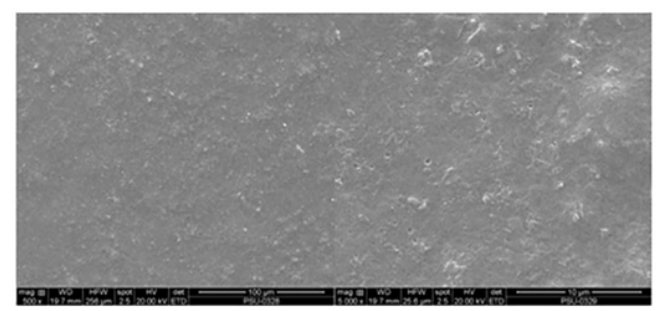

Adhesive

B

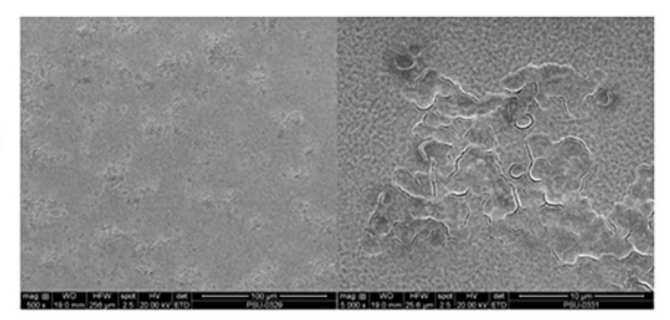

Cross-section
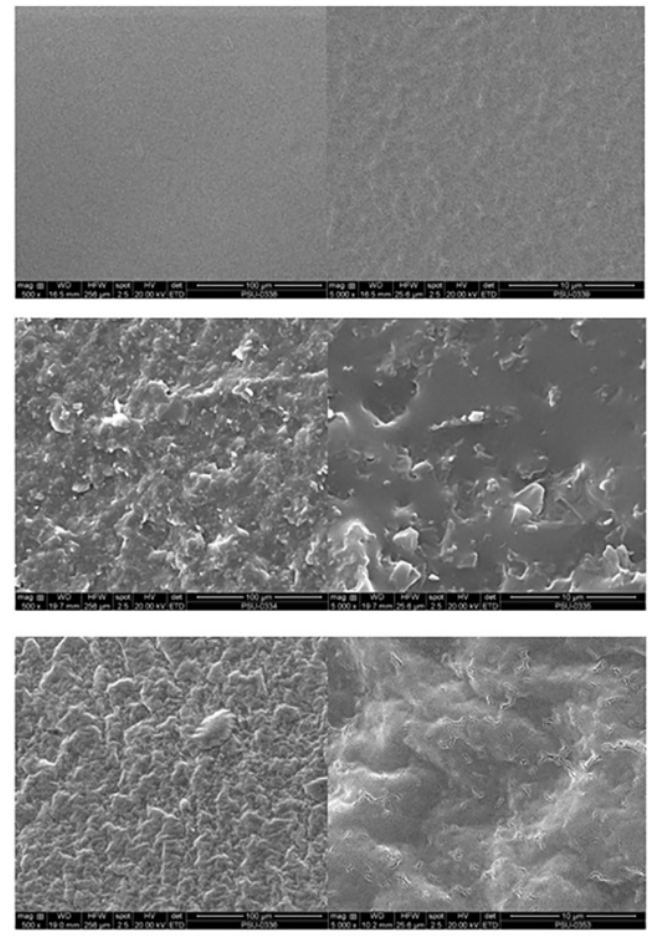

FIGURE 8. Scanning electron images of the films of Control, Adhesives A and B on surface and cross-section views at low and high magnification

\section{DISCUSSION}

The production of commercial NRL on the industrial field has normally used toxic chemicals such as high concentrations of ammonia as a stabilizer that causes irritation of the skin. Some allergenic proteins on the surface particles and in the serum of NRL are the cause of latex allergies in both mild and severe levels (Brehler \& Kütting 2001; Kumar 2012). These would be unsuitable for skin preparations. The DNRL solution prepared by Pichayakorn et al. (2013b) used proteolytic alcalase enzymes, followed by centrifugation removing the allergenic protein from fresh NRL had low protein content. In addition, the DNRL was safe to apply to the skin of New Zealand rabbits (Pichayakorn et al. 2012c).

A useful technique for developing materials with properties superior to those of individual constituents is blending technique which this study focuses on blending of DNRL with adhesive polymer to achieve adhesive property of DNRL adhesive. The different properties depend on the type and load of polymer blend and additives. In a previous study, DNRL blended with adhesive polymers (hydroxypropylmethyl cellulose; HPMC) or PVA and plasticizers provided the suitable films with elastic and adhesive properties for medical and pharmaceutical skin applications (Pichayakorn et al. 2012c). They have also reported on preparation and evaluation of nicotine delivery system derived from these blended films. Results showed that DNRL blended with PVA and dibutyl phthalate or glycerin were the most proper ingredients to form completed films of filmforming polymeric solutions and these solutions could be prepared for transdermal nicotine delivery systems (Pichayakorn et al. 2013b).

In this study, the adhesive formulations were developed from non-vulcanized natural rubber-based adhesives (Adhesive A), and pharmaceutical DNRL products (Adhesive B) for skin, such as transdermal drug delivery, peel-off mask, and cosmetic pore pack. The formulation of Adhesive A contained up to different components, such as DNRL, adhesive polymer, tackifiers, antioxidants, and thickeners. The formulation of 
Adhesive B is composed of DNRL, PVA, plasticizers, stabilizers, and preservatives. The Adhesive B contains paraben as a preservative which may be carcinogenic but Adhesive A has none, but the biocompatibility results of Adhesive A and Adhesive B showed similar percentage viability. These may be due to the minimal percentage of the paraben $(0.25 \mathrm{phr})$.

MDX4-4201 was used as a substrate for peel bond strength because it eases to manipulate which is prepared by stone molds at room temperature (Andres et al. 1992). Moreover, it exhibits adequate mechanical properties and biologically compatible (Cruz et al. 2020; Haug \& Andres 1992a, 1992b). The component of MDX44210 is polydimethylsiloxane, reinforcing silica, and a platinum catalyst. Retention of maxillofacial prostheses consists of natural teeth clasps, precision attachment, non-rigid attachments, magnets, anatomic undercuts, adhesives, and implants. This research focuses on the retention derived from skin adhesive which still important for patients with a limited budget and afraid of implant surgery. The adhesive for silicone elastomer used maxillofacial prosthesis should be fast skin wettability during initial adhesion, suitable bond the prosthesis to the adherent, and readily removed from the prosthesis and adherent after de-bonding. In these results, the $15 \%$ and 20\% PVA at $15 \mathrm{phr}$ as Adhesive A and B blending in DNRL were the most appropriate polymers for forming DNRL adhesive with proper adhesive properties because the structure of PVA molecule has many hydroxyl groups which form hydrogen bonds affecting excellent properties of PVA (Landrock \& Ebnesajjad 2008). They have also been employed for different pharmaceutical and biomedical applications (DeMerlis \& Schoneker 2003; Figueiredo et al. 2009). Previous research showed that PVA can blend with DNRL in order to improve adhesive properties of DNRL used in pharmaceutical applications such as nicotine transdermal patch (Pichayakorn et al. 2013b, 2012a, 2012b).

In Adhesive A and Adhesive B, the tackifier resin had significant effects on the peel bond strength of the novel DNRL adhesive. Blending coumarone resin with DNRL improved adhesive properties more than pure DNRL and PVA did. This indicated that the adhesion improvement was obtained by blending tackifier resin into the DNRL due to the properties of tackifier resin which improve wettability to the substrate and achieved bonding. The bond strength was increased when DNRL was blended with tackifier resin that was similar to those found in previous research. The amount of tackifier and filler in adhesive affect tack value and peel bond strength when increasing tackifier and filler up to optimum, increasing bond strength were observed. And then, decreasing of bond strength when tackifier and filler over optimum (Poh \& Kwo 2007; Poh et al. 2008).

The other additives also determine their adhesive properties. Accelerators are added to reduce the vulcanization time such as with ZDEC (Benedek \& Feldstein 2008) Wing stay L. are antioxidants for rubberbased adhesives. Antioxidants can maintain the properties of rubber-based adhesives from changing during their shelf life. The thermal and ozone exposition and UV light frequently induce oxidative changes of polymer which present the degree of unsaturation in polymer backbone of NR (Benedek \& Feldstein 2008; Pizzi \& Mittal 2003). CMC as thickeners is added to increase the viscosity of the NR adhesives. Methylcellulose and derivatives are commonly used in food and pharmaceutical industries and used as a lubricant in artificial tears because it has a high viscosity, non-toxic, and hypoallergenic (Krizova \& Wiener 2013).

In Adhesive B, plasticizers are added to decrease the viscosity of a material due to increasing intermolecular spacing and molecular mobility and enhancing tack value which the plasticizers are used in the adhesives to improve the performance of adhesive. The previous study improves the adhesiveness of DNRL latex by blending it with plasticizer and adhesive polymer (Pichayakorn et al. 2012c). In contrast, the different amounts of plasticizer incorporation in this study had no significant difference in adhesive properties. The $30 \mathrm{phr}$ glycerin with $10 \%$ PVA showed slight decreases in bond strength. Therefore, the $30 \mathrm{phr}$ plasticizer was removed from the DNRL adhesive with $15 \%$ and $20 \%$ PVA. The over optimum of plasticizers added into the DNRL adhesive significantly decreased the peel bond strength, which was due to over increasing intermolecular spacing and molecular mobility. Thus, 10 phr glycerin was the most proper plasticizer to provide proper adhesive and they show the effect of making the moisture to the skin and no effect on the peel bond strength. Another additive is polysorbate 80 (Tween80) which is a nonionic emulsifier and surfactant used in foods and cosmetics such as ice cream. This additive has not been found to be carcinogenic.

The limitation of this research is the deficiency of microbial analyses to confirm microorganisms in the adhesive which might play an important role in the increase in sensitivity of adhesive. Moreover, lack of sensitivity and irritation tests on animals and humans which further research will focus on irritation tests. 


\section{CONCLUSION}

The novel deproteinized natural rubber latex (DNRL) adhesive developed from non-vulcanized natural rubber-based adhesives and pharmaceutical DNRL were successfully developed from natural rubber latex. Both adhesives were physically and chemically stable at temperature $4{ }^{\circ} \mathrm{C}$ and had suitable peel bond strength adhesives as the commercial adhesive. The adhesives were biocompatible. Hence, the adhesives can be used to adhere to the maxillofacial silicone prostheses.

\section{ACKNOWLEDGEMENTS}

The authors would like to express their gratitude to Assistant Professor Dr. Ekwipoo Kalkornsurapranee from the Faculty of Science, Prince of Songkla University. This research was supported by the Maxillofacial Prosthodontics and Dental Materials Research Unit, Faculty of Dentistry, Prince of Songkla University and Scholarship Award of Thai Ph.D. student under Thailand's Education Hub for Southern Region of ASEAN countries, Prince of Songkla University.

\section{REFERENCES}

Amornvit, P., Rokaya, D. \& Sanohkan, S. 2019. Applications of PEEK in implant retained finger prosthesis. J. Int. Dent. Med. Res. 12(4): 1606-1609.

Andres, C.J., Haug, S.P. \& Munoz, C.A. 1992. Effects of environmental factors on maxillofacial elastomers Part I literature review. J. Prosthet. Dent. 68: 327-330.

Benedek, I. \& Feldstein, M.M. 2008. Technology of PressureSensitive Adhesives and Products. Boca Raton: CRC Press.

Brehler, R. \& Kütting, B. 2001. Natural rubber latex allergy: A problem of interdisciplinary concern in medicine. Arch. Intern. Med. 161(8): 1057-1064. doi:10.1001/ archinte.161.8.1057.

Charoenkijkajorn, D. \& Sanohkan, S. 2020. The effect of nano zinc oxide particles on color stability of MDX4-4210 silicone prostheses. European Journal of Dentistry 14(4): 525-532.

Cruz, R.L.J., Ross, M.T., Powell, S.K. \& Woodruff, M.A. 2020. Advancements in soft-tissue prosthetics Part B: The chemistry of imitating life. Frontiers in Bioengineering and Biotechnology 8: 147. doi:10.3389/fbioe.2020.00147.

Dahl, J.E. \& Polyzois, G.L. 2000. Irritation test of tissue adhesives for facial prostheses. J. Prosthet. Dent. 84: 453457.

DeMerlis, C. \& Schoneker, D. 2003. Review of the oral toxicity of polyvinyl alcohol (PVA). Food Chem. Toxicol. 41(3): 319-326.

Figueiredo, K., Alves, T.L. \& Borges, C.P. 2009. Poly(vinyl alcohol) films crosslinked by glutaraldehyde under mild conditions. J. Appl. Polym. Sci. 111(6): 3074-3080.
Haug, S.P. \& Andres, C.J. 1992a. Effects of environmental factors on maxillofacial elastomers Part III-Physical properties. $J$. Prosthet. Dent. 68: 644-651.

Haug, S.P. \& Andres, C.J. 1992b. Effects of environmental factors on maxillofacial elastomers Part IV-optical properties. $J$. Prosthet. Dent. 68: 820-823.

Haug, S.P., Richard, G.E., Margiotti, E. \& Winkler, M.M. 1995. An in vivo evaluation of adhesives used in extraoral maxillofacial prostheses. J. Prosthet. Dent. 4: 11-15.

Huber, H. \& Studer, S.P. 2002. Materials and techniques in maxillofacial prosthodontic rehabilitation. Oral Maxillofac. Surg. Clin. North Am. 14(1): 73-93.

ISO. 2009. 10993-5: 2009. Biological Evaluation of Medical Devices-Part 5: Tests for In Vitro Cytotoxicity. Geneva: International Organization for Standardization.

Jazayeri, H.E., Kang, S., Masri, R.M., Kuhn, L., Fahimipour, F., Vanevenhoven, R., Thompson, G., Gheisarifar, M., Tahriri, M. \& Tayebi, L. 2018. Advancements in craniofacial prosthesis fabrication: A narrative review of holistic treatment. The Journal of Advanced Prosthodontics 10(6): 430-439. doi:10.4047/jap.2018.10.6.430.

Khan, I. \& Poh, B. 2011a. Effect of molecular weight and testing rate on adhesion property of pressure-sensitive adhesives prepared from epoxidized natural rubber. Mater. Des. 32(5): 2513-2519.

Khan, I. \& Poh, B. 2011b. Natural rubber-based pressuresensitive adhesives: A review. J. Polym. Environ. 19(3): 793.

Kiat-amnuay, S., Waters, P.J., Roberts, D. \& Gettleman, L. 2008. Adhesive retention of silicone and chlorinated polyethylene for maxillofacial prosth. J. Prosthet. Dent. 99: 483-488. doi:10.1016/S0022-3913(08)60113-4.

Krizova, H. \& Wiener, J. 2013. Development of carboxymethyl cellulose/polyphenols gels for textile applications. Autex Res. J. 13(2): 33-36.

Kumar, R.P. 2012. Latex allergy in clinical practice. Indian Journal of Dermatology 57(1): 66-70. doi:10.4103/0019. 5154.92686.

Landrock, A.H. \& Ebnesajjad, S. 2008. Adhesives Technology Handbook. 3rd ed. Norwich: William Andrew.

Nanti, S., Wongputtisin, P., Sakulsingharoj, C., Klongklaew, A. \& Chomsri, N. 2014. Removal of allergenic protein in natural rubber latex using protease from Bacillus sp. Food Appl. Biosci. J. 2(3): 216-223.

Perrella, F.W. \& Gaspari, A.A. 2002. Natural rubber latex protein reduction with an emphasis on enzyme treatment. Methods 27(1): 77-86.

Pichayakorn, W., Boonme, P. \& Taweepreda, W. 2014a. Cosmetic Pore Packs from Deproteinized Natural Rubber Latex. Paper presented at the Adv. Mat. Res.

Pichayakorn, W., Suksaeree, J. \& Taweepreda, W. 2014 b. Improved Deproteinization Process for Protein-Free Natural Rubber Latex. Paper presented at the Adv. Mat. Res.

Pichayakorn, W., Boonme, P. \& Taweepreda, W. $2013 \mathrm{a}$. Preparation of Peel-off Mask from Deproteinized Natural Rubber Latex. Paper presented at the Adv. Mat. Res. 
Pichayakorn, W., Suksaeree, J., Boonme, P., Amnuaikit, T., Taweepreda, W. \& Ritthidej, G.C. 2013b. Deproteinized natural rubber film forming polymeric solutions for nicotine transdermal delivery. Pharm. Dev. Technol. 18(5): 11111121.

Pichayakorn, W., Suksaeree, J., Boonme, P., Amnuaikit, T., Taweepreda, W. \& Ritthidej, G.C. 2012a. Deproteinized natural rubber latex/hydroxypropylmethyl cellulose blending polymers for nicotine matrix films. Ind. Eng. Chem. Res. 51(25): 8442-8452.

Pichayakorn, W., Suksaeree, J., Boonme, P., Amnuaikit, T., Taweepreda, W. \& Ritthidej, G.C. 2012b. Nicotine transdermal patches using polymeric natural rubber as the matrix controlling system: Effect of polymer and plasticizer blends. J. Memb. Sci. 411: 81-90.

Pichayakorn, W., Suksaeree, J., Boonme, P., Taweepreda, W. \& Ritthidej, G.C. 2012c. Preparation of deproteinized natural rubber latex and properties of films formed by itself and several adhesive polymer blends. Ind. Eng. Chem. Res. 51(41): 13393-13404.

Pichayakorn, W., Suksaeree, J., Boonme, P., Taweepreda, W. \& Ritthidej, G.C. 2012d. Preparation of deproteinized natural rubber latex and properties of films formed by itself and several adhesive polymer blends. Industrial \& Engineering Chemistry Research 51(41): 13393-13404. doi:10.1021/ ie301985y.

Pizzi, A. \& Mittal, K.L. 2003. Handbook of Adhesive Technolgy. 2nd ed. New York: Marcel Dekker.

Poh, B. \& Kwo, H. 2007. Peel and shear strength of pressuresensitive adhesives prepared from epoxidized natural rubber. J. Appl. Polym. Sci. 105(2): 680-684.

Poh, B., Lee, P. \& Chuah, S. 2008. Adhesion property of epoxidized natural rubber (ENR)-based adhesives containing calcium carbonate. Express Polym. Lett. 2(6): 398-403.

Polyzois, G.L. \& Dahl, J.E. 1993. Tensile bond strength of maxillofacial adhesives J. Prosthet. Dent. 69: 374-377.

Sakdapipanich, J.T. \& Rojruthai, P. 2012. Molecular structure of natural rubber and its characteristics based on recent evidence Biotechnology-Molecular Studies and Novel Applications for Improved Quality of Human Life: InTech.
Sherriff, M., Knibbs, R. \& Langley, P. 1973. Mechanism for the action of tackifying resins in pressure-sensitive adhesives. $J$. Appl. Polym. Sci. 17(11): 3423-3438.

Sommer, S., Wilkinson, S., Beck, M., English, J., Gawkrodger, D. \& Green, C. 2002. Type IV hypersensitivity reactions to natural rubber latex: Results of a multicentre study. $B r . J$. Dermatol. 146(1): 114-117.

Suksaeree, J., Pichayakorn, W., Monton, C., Sakunpak, A., Chusut, T. \& Saingam, W. 2014. Rubber polymers for transdermal drug delivery systems. Ind. Eng. Chem. Res. 53(2): 507-513.

Taylor, J.S. \& Erkek, E. 2004. Latex allergy: Diagnosis and management. Dermatol. Ther. 17(4): 289-301.

Thongpulsawasdi, N., Amornvit, P., Rokaya, D. \& Keawcharoen, K. 2014. Adhesive vs implant retained fingers prosthesis: A comparative study on esthetic and functional outcome. World Appl. Sci. J. 29(8): 1015-1019.

Ventura, M., Dagnello, M., Matino, M., Di Corato, R., Giuliano, G. \& Tursi, A. 2001. Contact dermatitis in students practicing sports: Incidence of rubber sensitisation. Br. J. Sports Med. 35(2): 100-102.

Paweena Kongkon \& Sasiwimol Sanohkan*

Department of Prosthetic Dentistry

Faculty of Dentistry

Prince of Songkla University

Songkhla 90112

Thailand

Wiwat Pichayakorn

Department of Pharmaceutical Technology

Faculty of Pharmaceutical Sciences

Prince of Songkla University

Songkhla 90112

Thailand

*Corresponding author; email: sanohkan.psu@gmail.com

Received: 5 January 2021

Accepted: 8 March 2021 